ANNALS, $A A P S S, 473$, May 1984

\title{
Work Place Democracy and Quality of Work Life: Problems and Prospects
}

\author{
By HY KORNBLUH
}

\begin{abstract}
The concept of increasing the participation of workers in decisions affecting their work lives is appearing more often on the labormanagement agenda. The reasons for management interest include the need for (1) increasing productivity and quality; (2) increasing the quality of work life for the new worker, who is more educated, with a good work ethic but alienated and unmotivated under current management practice; and (3) meeting foreign competition. Problems may arise for firms involved in forms of participation such as quality circles and quality of work life programs, when management aims of a streamlined work force and control of worker innovations clash with the workers' expectations of work place democracy inherent in such programs. A dilemma is posed for unions when the new forms of participation undermine the union, or maintain or create so-called union-free environments. Many unions are now playing a more active role in these programs. More aggressive approaches to bargaining on work environment and other issues reflect movement by some unions to a more proactive philosophy of the union's role in participation-enhancing strategies.
\end{abstract}

Hy Kornbluh is director of the Labor Studies Center, Institute of Labor and Industrial Relations, and teaches at the University of Michigan. He is director of a research project, "Employee Participation in Conservation: The U.S. and Japan Experience" and has studied the Swedish Industrial Democracy Act of 1977 on a Swedish Information Service grant. Guest editor of a special issue of the Labor Studies Journal, "Unions, Labor Education, and Workers' Participation," he also chairs the Task Force on Workers' Participation of the University and College Labor Education Association. 
$\mathrm{T}^{\mathrm{H}}$ HE idea of increasing workers'participation directly in decisions affecting how their work is done and the quality of their work life is appearing on the labor-management agenda in forms that present new challenges to unions in organized industries and perhaps even greater challenges in many unorganized work places. This thrust has been generated by a complex set of economic, demographic, and technological circumstances, changing worker expectations, and worker and employer motivations. Although this may be only a passing fad in many enterprises-many participation plans are what Pateman has called "pseudo participation"1 and many thus fold very early ${ }^{2}$ - the phenomenon has the potential of having a longer lasting role in an increasing number of unionized work places. The future of these developments will depend on the employers' willingness to modify significantly traditional control and decisionmaking patterns and, where the union is strong, on labor's assumption of a neutral or active role in the arrangements.

As part of a recent case-study research team, I looked at employee involvement groups among the production workers, particularly those groups undertaking energy conservation projects in a large Midwest manufacturing plant. One of the coordinators of the program in that establishment suggested that we study similar white-collar teams they had

1. Carole Pateman, Participation and Democratic Theory (Cambridge: Oxford University Press, 1970).

2. See P. S. Goodman, "Quality of Work Projects in the 1980s," in Proceedings of the Thirty-third Annual Meeting of the Industrial Relations Research Association (Madison, WI: IRRA, 1981), pp. 489-91; he found that a large percentage of quality circle programs did not last beyond five years. formed there. One of these teams had indeed carried through an imaginative, high-savings conservation project. However, after a close look we found that the greater concern of some teams, which were trained in participative problem solving, was to develop work-simplification projects for the blue-collar work force. Such projects are a sophisticated, contemporary Tayloristic approach to designing work. Ironically, quality of work life (QWL)-type programs in many industries are designed to offset if not the practice then the effects of work rationalization that result in atomized, repetitive, boring jobs designed to minimize worker discretion as much as possible.

This situation highlights some of the currents and crosscurrents surrounding the relatively new kid on the labormanagement relations block who is being introduced under various names and forms, such as quality of work life, quality circles (QC), employee involvement programs, worker participation, participative management, work reform, work redesign, and so forth. ${ }^{3}$

In addition to this trend, some unions are also attempting to expand worker influence in new areas of collective bargaining. Whichever way they may relate to these developments, unions are faced with certain choices, dilemmas, and challenges to traditional organizing appeals,

3. Quality circles and quality of work life groups are volunteer groups of usually 7-12 employees who identify and work on solutions to problems in the way their work is done. QWLs tend to have a more open agenda than QCs. A more advanced form of participation is involved in autonomous or semi-autonomous work groups that take responsibility for many aspects of the work station traditionally reserved for supervision, often including designing the work, pay, and hiring and teaching new employees. 
leadership styles, and labor-management philosophy. For employers, shortterm gains from these programs may also present long-term dilemmas.

\section{WHAT IS HAPPENING TODAY}

There is substantial expansion in participative programs, covering a range of industries and taking a variety of forms. Although no systematic study of the breadth and depth of what is happening has been conducted, some limited data exist, and there is a strong indication that interest in these developments and further experimentation will continue.

A recent study in early 1982 by the New York Stock Exchange surveyed a representative sample of 49,000 U.S. corporations employing 41 million employees in units with more than 100 employees. The results indicate a great acceleration of interest in QWL-related activities in the last two years, particularly in manufacturing. They include these findings:

1. Three out of four companies with QCs have had them for less than two years. Fifty-eight percent of manufacturing firms with human resource programs have QCs, compared to 27 percent in nonmanufacturing. The larger the manufacturing company, the more likely it is to have a QC program. Three out of four companies with 10,000 or more employees have QCs.

2. When asked whether participative management is a "fad destined to disappear" or "a promising new approach," 83 percent of all corporations said it was the latter. ${ }^{4}$

4. People and Productivity: A Challenge to Corporate America (New York: New York Stock Exchange, 1982), pp. 26, 27, 50.
To be sure, the percentage of workers involved in participative programs in these corporations is far below a majority. Nevertheless, the figures present an impressive display of expanding interest and involvement by increasing numbers of workers and managers in such programs.

The Ford Motor Company may not be representative of other large-scale corporations, yet it is worth listing some of its developments in participative decision making. As of the middle of 1983 , 65 of Ford's 90 U.S. plants were in the program, with a total of more than 11,000 employees involved in voluntary problem-solving groups or more extensive decision-making roles. The president of Ford has gotten squarely behind these efforts. As a result of their last contract negotiations, a United Automobile Workers-Ford joint decisionmaking structure for developing retraining and education programs for laid-off workers and those still on the payroll is now functioning. In addition, a contract-mandated, formal joint consultation structure for the union to share information at various levels of the company through what the contract calls "mutual growth forums" is beginning to function in some locations. One division of Ford is systematically attempting very intensive training in participative management in groups that make a vertical slice through the division's managerial hierarchy.

General Motors and the United Automobile Workers have a parallel joint retraining program. There is also an extensive QWL effort that predates the start of the Ford program, but that has lagged behind Ford in the momentum of more recent expansion. The Communication Workers of America has had an 
agreement on an industry-wide QWL program. In the 1982 contract, the union bargained for prior notice of and consultation on new technology.

More intensive participative structures that go beyond the normal QWL are also developing. Basil Whiting, a long-time observer in this field, has indicated that, until recently, semi-autonomous, autonomous, and self-managing work groups have been relatively rare in this country. But, he says,

in as many as two or three dozen new plant designs in this nation, there are startlingly flat organizational structures and work groups without apparent supervision except what they provide to themselves. Members are cross-trained and rotate among clusters of tasks. They hire, fire, and discipline themselves. They are often paid according to the number of jobs they know as judged by their peers, and share in what appear to be quite high profit levels for their kind of facility. They also engage in the kinds of planning and coordinating usually done by top-line managers in normal plants.

Workers'participation in work-place decision making is also linked to the recent intensification of the phenomenon of worker ownership in two ways:

1. A number of the worker takeovers, although motivated primarily by job preservation, have redesigned the work-place decision-making structure to include high levels of worker-owner participation in decision making on the job-site and plant levels. Through problem-solving groups, workers consider and make recommendations on a broader range of decisional areas than the usual QWL or QC programs. There are

5. Basil J. Whiting, "QWL: All or Nothing at All ... ?" (Discussion draft, Michigan Quality of Work Life Council, Troy, MI, 1983). also a significant number of workerelected representatives on the board of directors. Recent examples of this kind of enterprise include the General Motors Hyatt-Clark plant in New Jersey and the Rath Packing Company in Iowa.

2. Most worker-owned plants are employee stock ownership plans (ESOPs), which have no participative decisionmaking features and are started by traditional managers for the tax breaks and employee financial participation as a source of ready capital. Although employees start out with no voting rights, the law prescribes that such rights become operative after a number of years in many ESOPs. Thus there may emerge in the future a number of enterprises where employees may pool their voting rights to establish more participative control, particularly if the enterprises described above provide attactive models for their workers.

\section{MANAGEMENT INTERESTS AND DILEMMAS}

Why are many managers interested in QWL and QC schemes or work restructuring programs, such as autonomous work groups?

Many managers have seen participative programs as a vehicle for (1) dealing with worker alienation in an over-educated work force that, it is claimed, frequently results in absenteeism, drug abuse, low morale, and other expressions of worker dissatisfaction; and (2) increasing productivity through enhanced job satisfaction and through harnessing the skills and ideas of those responsible for doing the work.

A cohort of managers are aware that "the new workers"- the younger, bettereducated workers-- are very much more 
resistant to authoritarianism and seek more challenge and meaning in work than the last generation of workers. In addition, Yankelovich and Immerwahr have suggested that the shift toward service and information industries has also meant a shift in job structure, with a greater proportion of high-discretion job holders, those who have a great deal of say over their own performance. They claim that many of these workers, who could easily be motivated to increase the quality and quantity of their input, currently have low motivation under existing management practices that are holdovers from managerial styles developed in the early part of the century. ${ }^{6}$

The earlier concern for dealing with worker alienation has been surpassed more recently by an overarching concern by managers - and many union leaders and members - with meeting the threat of foreign competition in many of the basic industries in this country. Many U.S. managers and some union leaders have been attracted to emulating the role of the quality circle movement in establishing Japan's enviable production record.

A number of analysts have suggested that managers looking to the work place of the future identify the need for workers who are adaptable and who are skilled in working in problem-solving teams that understand the new technology of their work places. Hirschhorn has given an excellent analysis of the need for workers who are trained to analyze the whole system through group problem solving, instead of being famil-

6. Daniel Yankelovich and John Immerwahr, Putting the Work Ethic to Work (New York: Public Agenda Foundation, 1983), pp. 5, 6. iar with only the narrow mechanics of their own operation in one specific part of the system.?

In all, there is something of a contest going on in the U.S. management world as to whether some significant change in relationships between managers and employees is going to take place. On the one hand, there is the authoritarian, bureaucratic, centralized control approach that includes continuing to view the work world primarily through Tayloristic work-simplification practices. It emphasizes larger short-term gains than some participative programs may be able to produce, even though well-constructed QWL programs often appear to make early impressive gains in absenteeism, reduction of grievances, increases in quality, and reduction in scrap. These management practices are inclined toward shaking up or shaking out the union in the current period of union vulnerability through concession bargaining and/or abetting decertification elections. Thus a 1980 study showed the anomaly of U.S. multinational executives in Western Europe who adapted well to mandated worker participation there, but who opposed such programs in the United States as un-American. ${ }^{8}$

In contention is a developing management perspective and style that is change-oriented; more open; willing to adopt and adapt to more participative

7. Larry Hirschhorn, "The Soul of a New Worker," Working Papers, pp. $42-47$ (Jan.-Feb. 1982); for his more elaborate analysis of the future world of work and its implications, see "The PostIndustrial Labor Process," New Political Science, no. 7, pp. 11-31, (Fall 1981).

8. Tom De Vos, U.S. Multinationals and Worker Participation in Management: The American Experience in the European Community (Westport, CT: Quorum Books, 1981). 
management methods while being less fearful of shared decision making. It is more empathic to the workers'desire for more meaningful, challenging work and understanding of the need for a more adaptive, flexible work force in the emerging world of work. This perspective employs these approaches to maintain or enhance profitability and competitiveness.

This management weltanschauung may be reinforced as (1) the shift continues to industries requiring more flexible, problem-solving workers who at the same time form a greater cohort of high-discretion job holders; (2) the 1960s' generation moves into position as the backbone of the work force; and (3) the replacement of old production units and expansion in the newer, developing industries present the opportunity to design new work facilities with more intensive participation opportunities.

The participative approach is not without its problems, however, for managers may face a dilemma brought on by the dynamics of meaningful participation. It is best described by Derber and Schwartz, whose analysis is undergirded by empirical research from a number of sources. ${ }^{9}$ They suggest that this new approach resolves

some of the strains engendered by conventional structures, but in its very solution sets into motion other forces producing a new fundamental strain.... [These] projects generate increased worker competencies, expectations, and desires for job challenge, autonomy, and in our interpretation self-governance. These, in the long run, are inconsistent with the institutional boundaries of

9. Charles Derber and William Schwartz, "Toward a Theory of Worker Participation," Sociological Inquiry, 53(1):61-76 (Winter 1983). authority in the new system. . . Put most simply, the relative autonomy in the labor process required to reduce worker alienation and increase worker integration also "empowers" workers psychologically to seek wide autonomy in the workplace, thereby placing strains on the existing boundaries of authority.

Thus the solution to current work-design problems may well engender new expectations on the part of the workers involved.

\section{UNION INVOLVEMENT AND DILEMMAS}

Unions have to start with the premise that well-designed and well-executed participation programs have a strong appeal for their members or potential members. It was put quite simply, but forcefully, by a long-time United Automobile Workers' member who volunteered for one of the early meetings of her departmental problem-solving group: "I've been working here for 28 years and this is the first time anyone, union or management, asked me what I think."

The trends toward worker participation present the labor movement with a situation that may have many opportunities for unions and their members on the one hand and some basic threats and dilemmas on the other, as this issue is played out in the internal union political process and, currently, in a recessionary and increasingly antiunion external environment. They raise a number of issues: what role the unions should play under what circumstances; what strategies to follow if this is to be a vehicle for advancing work-place democracy; and whether to accept this as a purely labormanagement cooperation phenomenon 
or one that also has implications for the scope and philosophy of union bargaining.

Many union leaders have concluded or reaffirmed their belief that management has not really accepted unionism in the United States. They bolster their claims by citing current intensified employer efforts to create or to maintain so-called union-free environments. They point to the roles played by many management consultants who sell an antiunion package that includes using participative management approaches with the work force as a means of enhancing workers' loyalties to management rather than to unions.

A second kind of dilemma occurs at the local level. What should be done when a QC or QWL program is introduced with or without an invitation to the union to participate? Will this program be designed to undermine the union if the union is neutral or is too weak to oppose the plan effectively? Will it be used to enhance straight productivity or product quality? Should it be used as an important process to keep the local plant competitive with other companies in and out of the United States? What about competition with other plants in the same company, and thus in the same union, where the com. pany has decided, or is threatening, to close one or more plants producing the same product?

With members' jobs threatened by foreign competition, many unions have decided that they can be party to arrangements for increasing quality and productivity as long as the effort is not designed to reduce jobs for their members. In practice, this is difficult to do, as many participative efforts are being instituted at the same time as recessionbased layoffs are taking place. In all, some union leaders, satisfied that they can keep the QWL effort from undermining their union and its collective bargaining function, are actively entering participative arrangements in order to have the program serve their overall interests as well as management's.

Within the context of viewing the expansion of work-place democracy as a means of enlarging the direct or indirect control workers have over the decisions that affect their lives, other developments are important for understanding the future of expanding participation in this country. More unions are developing a concept of the work environment and the need to gain more control over it through collective bargaining and other labor-initiated approaches. Drawing on the Norwegian experience with workplace democracy policy, Steven Deutsch suggests that health and safety, including stress and the problems raised by new technology, is an area for enlarging work-place decision making, since workers feel strongly that these problems affect them directly. This suggests that unions should strive for meaningful participation in the decisions related to these issues. ${ }^{10}$

Some unions are now assuming a proactive approach to issues such as health, safety, and technological change rather than a reactive approach - the traditional union stance of dealing with the consequences, rather than the prevention, of certain work-place-related problems. In the field of technological change, for example, the Communication Workers of America have negotiated the right to be notified of and consulted on new technological deci-

10. Steven Deutsch, "Extending Workplace Democracy: Struggles to Come in Job Safety and Health," Labor Studies Journal, 6(1):124-32(1981). 
sions. Recently, the International Association of Machinists (IAM) local at Eastern Airlines fought hard to win negotiated joint decision making on their pension fund investment policy. The Eastern Airlines negotiation is part of a strategy by a number of unions to participate in decisions about how the billions of dollars of members' pension funds-currently invested by nonunion decision makers and, ironically, sometimes in antiunion enterprises-are invested in the future. It is not outside the realm of possibility that the collective bargaining process might be used to determine that such funds foster enterprises that are managed by those dedicated to designing economically viable and truly democratic work places.

The same IAM local, involved with other Eastern Airlines unions in concession bargaining, recently negotiated a quid pro quo of involvement in important traditional management decisionmaking areas and structures, including participation in restructuring the company, worker involvement in designing new facilities, and union-controlled seats on the company's board of directors.

Thus change is taking place in union philosophy and involvement relating to decision making at the job-site and corporate levels. Though contrary to traditional union philosophy, some union leaders - fueled by the recent recession, the rash of plant closings, and the failure of U.S. management in international competition-are beginning to feel, as expressed by noted labor analyst B. J. Widick, that "management is too important to be left to managers." I Viewing the future of work-place participation programs, Douglas Fraser, the recently retired United Automobile Workers president and member of the Chrysler Corporation board of directors, was optimistic about their expansion. He said, "There's no turning back." "12

11. Speech delivered at Wayne State University, Nov. 1983.

12. Speech delivered at the University of Michigan, 5 Dec. 1983. 